\title{
Choroba w wybranych pismach Izydora z Sewilli
}

W bogatej spuściźnie pisarskiej Izydora z Sewilli poza słynnymi Etymologiami (Etymologiae) znajdujemy liczne, różnorodne dzieła o tematyce teologicznej (doktrynalnej, egzegetycznej, liturgicznej) i świeckiej (gramatycznej, przyrodniczej, historycznej), pisane prozą i wierszowane, przeznaczone dla ogółu czytelników oraz skierowane do bliskich przyjaciół². Czy istnieje centralny temat pisarstwa Sewilczyka? Jeżeli istnieje, jaki on jest? Izydor pragnął poznać wszystko, a we wszystkim Boga, którego odkrywał w Biblii, sakramentach, stworzeniu. Właśnie dlatego, jak się wydaje, Thomas O'Loughlin sprawiedliwie stwierdza, że Izydor był w istocie teologiem, czyli kimś, kto dąży do ujęcia całej stworzonej rzeczywistości w świetle Objawienia ${ }^{3}$. Zauważmy, że równocześnie był on prawdziwym humanistą. Będąc uczonym „bibliotecznym", gdyż jego wiedza o świecie niewątpliwie miała charakter literacki, nigdy nie stał się uczonym ,gabinetowym”, ponieważ angażował się całym sobą w życie Kościoła i państwa Wizygotów, pozostając zawsze blisko ludzkich trosk, potrzeb, spraw. Przyglądał się człowiekowi, który oddaje hołd Bogu, tworzy alfabet, ustanawia prawa, zakłada państwa, szyje stroje, przemierza morza i warzy piwo, jest mówcą, lekarzem, rolnikiem, budowniczym, nadając każdej rzeczy jej imię, panuje nad światem oraz przemierza go, w trudach i bólach zmierzając do wieczności ${ }^{4}$, toteż - mówiąc słowami klasyka - nic, co ludzkie, nie

1 Dr hab. Tatiana Krynicka, profesor w Zakładzie Filologii Klasycznej Instytutu Studiów Klasycznych i Slawistyki Wydziału Filologicznego Uniwersytetu Gdańskiego; email: tatiana.krynicka@ug.edu.pl; ORCID: 0000-0002-0538-4205.

Por. T. Krynicka, Izydor z Sewilli, Kraków 2007, s. 17-74.

3 Por. T. O'Loughlin, Isidore of Seville as a Theologian, w: A Companion to Isidore of Seville, red. A. Fear - J. Wood, Leiden 2020, s. 135.

4 Por. Krynicka, Izydor, s. 68-69. 
było Izydorowi obce ${ }^{5}$. W niniejszym artykule chciałabym przyjrzeć się temu, jak w różnych, reprezentujących wszystkie wyżej wymienione działy jego piśmiennictwa dziełach Izydor przybliża swemu czytelnikowi problematykę choroby - zjawiska, które jest wpisane w nasz los i niezmiennie towarzyszy ludzkości mimo upływu wieków, rozwoju nauki i technologicznego postępu.

W Różnicach (Differentiae), jednym z najwcześniejszych swoich pism, poświęconym wyjaśnieniu rozbieżności znaczeniowych między wyrazami ${ }^{6}$, Izydor tłumaczy czytelnikowi, czym różnią się choroba (infirmitas) i zdrowie (valitudo), pisząc, że zdrowie może człowiekowi służyć, a może też sprowadzać nań nieszczęście (,et prospera esse potest et adversa"), podczas gdy choroba zawsze jest czymś niepotrzebnym, szkodliwym, nienawistnym, niebezpiecznym, groźnym, zgubnym (semper infesta est) ${ }^{7}$.

\section{Wiedza medyczna Izydora z Sewilli}

Sewilczyk nie był lekarzem, jednak medycyna, jak się wydaje, należała do tych dziedzin ludzkiej działalności, które darzył szczególnym zainteresowaniem ${ }^{8}$. Biblioteka sewilskich biskupów, w ścianach której zdobywał wiedzę o Bogu i Jego stworzeniu, gromadziła również pisma medyczne. Świadczy o tym zarówno skomponowany przez niego dystych, który mógł być zamieszczony przy odpowiednim regale ${ }^{9}$, jak też przede wszystkim wiadomości o różnorodnych schorzeniach, ich profilaktyce i leczeniu prze-

5 Por. Terentius, Heauton timorumenos, 77: ,homo sum: humani nil a me alienum puto".

6 Por. A. Ledzińska, Gramatyka wobec sztuk wyzwolonych w pismach Izydora z Sewilli. ,, Origo et fundamentum liberalium litterarum”, Kraków 2014, s. 52-56.

7 Isidorus Hispalensis, Differentiae I 40.

8 Por. F. Wallis, Isidore of Seville and Science, w: A Companion to Isidore of Seville, red. A. Fear - J. Wood, Leiden 2020, s. 206-207; B. Ribémont, Les origines des encyclopédies médiévales. D'Isidore de Séville aux Carolingiens, Paris 2001, s. 124.

9 Zwyczaj ozdabiania zwojów oraz bibliotek podobiznami autorów oraz poświęconymi im epigramatami był rozpowszechniony w starożytności. Por. L. Winniczuk, Ludzie, zwyczaje i obyczaje starożytnej Grecji i Rzymu, Warszawa 2006, s. 271; G.W. Houston, Inside Roman Libraries. Books Collections and Their Management in Antiquity, North Carolina 2014, s. 209-210. Izydor wspomina o nim w Etymologiach VI 5, 2 . 
kazane w jego słynnej encyklopedii ${ }^{10}$. W epigramacie szesnastego wiersza (Versus) $)^{11}$ czytamy:

Kosma. Damian. Hipokrates. Galen.

Obraz obecny przedstawia podobizny mężów wspaniałych,

Których na całym świecie czci medycyna jak mistrzów ${ }^{12}$.

Jak widzimy, poczet znakomitych medyków otwierają Kosma i Damian, bracia lekarze, którzy ponieśli śmierć męczeńską za panowania Dioklecjana $^{13}$. Po nich występuje Hipokrates z Kos (460-370), zdaniem Izydora trzeci, obok Apollina i Asklepiosa, twórca medycyny oraz potomek wspomnianych bogów ${ }^{14}$, uczony i lekarz-praktyk, któremu przypisywano autorstwo pism zebranych w Corpus Hippocraticum - pierwszym zbiorze naukowych tekstów antycznego świata ${ }^{15}$. Następnie biskup erudyta wymienia Galena (129-196), nadwornego lekarza Marka Aureliusza, stoika, uczonego, który przez wiele wieków wywierał duży wpływ na europejską medycynę ${ }^{16}$. Znajomość greki Sewilczyka była zdecydowanie za słaba, by mógł czytać pisma wspomnianych badaczy, nawet gdyby znajdowały się one w jego księgozbiorze. Jednakże ich dzieła kompilują oraz komentują, wspominają ich też z ogromną atencją i cytują, często imiennie, wszyscy starożytni autorzy piszący o medycynie, również twórcy znanych

10 Por. Ledzińska, Gramatyka, s. 90-98; J. Elfassi, Isidore of Seville and the „Etymologies”, w: A Companion to Isidore of Seville, red. A. Fear - J. Wood, Leiden 2020, s. 245-278.

11 Por. Ledzińska, Gramatyka, s. 37-40; T. Krynicka, Izydor z Sewilli, Wiersze, VoxP 50-51 (2007) s. 565-569.

$12 \mathrm{Tu}$ i dalej tłumaczenia tekstów obcojęzycznych pochodzą od autorki artykułu. Zdaniem niektórych badaczy, ten i dwa kolejne napisy poświęcone lekarzom, znajdowały się w przylegającej do biblioteki aptece. Por. M.C. Díaz y Díaz, Introducción general a San Isidoro de Sevilla, w: San Isidoro de Sevilla, Etimologías. Edición bilingüe, texto latino, versión española y notas, t. 1, opr. Oroz Reta - M.-A. Marcos Casquero, Madrid 1982, s. 154; J.C. Sánchez Martín, Introducción, w: Isidori Hispalensi Versus. Estudio literario, edicón critica, CCL 113a, Turnhout 2000, s. 27. Zauważmy jednak, że dokładna lokalizacja księgozbioru medycznego jest mało istotna.

13 Por. K. Kuźmiak, Kosma i Damian, EK IX 928.

14 Por. Isidorus Hispalensis, Etymologiae IV 3.

15 Por. R. Turasiewicz, Pisma medyczne. Corpus Hippocraticum, w: Literatura Grecji starożytnej, t. 2, red. H. Podbielski, Lublin 2005, s. 493-504.

16 Por. K. Korus, Nauka i studia nad filozofia, w: Literatura Grecji starożytnej, t. 2, red. H. Podbielski, Lublin 2005, s. 897-905. 
Sewilczykowi pism łacińskich. Należy do nich między innymi anonimowy autor łacińskiego Komentarza do Aforyzmów Hipokratesa (Commentarius in Aphorismos Hippocratis $)^{17}$ oraz Kwintus Gargiliusz Marcjalis, którego Lekarstwa $z$ warzyw i owoców (Medicinae ex holeribus et pomis) ${ }^{18}$ wielokrotnie dostarczają Izydorowi wiadomości o właściwościach leczniczych roślin prezentowanych przezeń w XVII księdze Etymologii (Etymologiae) ${ }^{19}$.

$\mathrm{Z}$ kolejnych zamieszczonych we wspomnianym zbiorku epigramatów wynika, że w pobliżu biblioteki znajdowało się pomieszczenie zwane pigmentarium. Była to apteka, w której przechowywano ,w małych naczyniach z kruchej, nietrwałej glinki"20, a przypuszczalnie również przyrządzano, głównie z roślinnych substancji, leki. Być może lekarz przyjmował tutaj chorych. Nie możemy wykluczyć, że wiedziony ciekawością Sewilczyk obserwował działania przebywających tam medyków - wymienia drogie, egzotyczne oraz ogólnie dostępne rośliny lecznicze ${ }^{21}$, opisuje woń poszczególnych maści ${ }^{22}$, zwraca uwagę, że lekarz nie może bogacić się kosztem ubogich chorych, aczkolwiek należy mu się godziwa zapłata od wszystkich pacjentów ${ }^{23}$. Jednakże wiedza medyczna Izydora - podobnie jak jego znajomość zoologii, botaniki czy mineralogii - ma charakter przede wszystkim literacki ${ }^{24}$. Dla filologa, który podejmuje badania nad jakimkolwiek spośród utworów biskupa erudyty, ustalenie jego źródeł pozostaje - jak trafnie ujął to Manuel Cecilio Díaz y Díaz - ,zadaniem niełatwym, niewdzięcznym, nieomal niewykonalnym" ${ }^{25}$. Udzielenie ostatecznej odpowiedzi na pytanie o dzieła, z których czerpał swą wiedzę medyczną, dodatko-

17 Por. M.E. Vásquez Buján, Isidoro de Sevilla y los libros de medicina, A propósito del antiguo comentario latino a los „Aforismos” hipocráticos, w: Isidorus medicus. Isidoro de Sevilla y los textos de medicina, red. A. Ferraces Rodríguez, A Coruña 2005, s. 131-174.

18 Por. T. Krynicka, Kwintus Gargiliusz Marcjalis - żotnierz, pisarz i ogrodnik, w: Gargiliusz, Lekarstwa z warzyw i owoców, tł. T. Krynicka, Wrocław 2016, s. 15, 19.

19 Por. J. André, Introduction, w: Isidore de Séville, Étymologies. Livre XVII De l'agriculture, Paris 1981, s. 9; T. Krynicka, Świat roślin w XVII księdze „Etymologii” Izydora z Sewilli, Lublin 2007, s. 72-75; B. Maire, Isidore de Séville, lecteur de Gargilius Martialis, w: Isidorus medicus. Isidoro de Sevilla y los textos de medicina, red. A. Ferraces Rodríguez, A Coruña 2005, s. 198-213.

20 Isidorus Hispalensis, Versus 24.

21 Por. Isidorus Hispalensis, Versus 19.

22 Por. Isidorus Hispalensis, Versus 20-23.

23 Por. Isidorus Hispalensis, Versus 17-18.

24 Por. T. Krynicka, Literacki charakter botanicznej wiedzy Izydora z Sewilli (,,Etymologie”, Księga XVII), ,Studia Classica et Neolatina” 9 (2010) s. 23-36.

25 M.C. Díaz y Díaz, Introducción, w: M.C. Díaz y Díaz, Los capítulos sobre los metales de las „Etimologías” de Isidoro de Sevilla, León 1970, s. 30. 
wo utrudnia brak nowego wydania krytycznego poświęconego medycynie IV księgi Etymologii oraz wielu pism medycznych, które mogły stanowić jego źródła ${ }^{26}$. Do autorów, najchętniej czytanych przez Izydora medyka należy Celiusz Aurelianus (V wiek po Chrystusie) - najwybitniejszy zdaniem Michaela von Albrechta łaciński pisarz medyczny schyłku antyku ${ }^{27}$. Jak się wydaje, Izydor znał jego dorobek pośrednio dzięki anonimowej przeróbce zatytułowanej Księga Aurelianowa (Liber Aurelianus) ${ }^{28}$. Wiadomości, przekazywane przez Sewilczyka, znajdujemy również w ośmiu księgach poświęconych medycynie (De medicina), które jako jedyne ocalały z encyklopedii Korneliusza Aulusa Celsusa (I wiek po Chrystusie), rzymskiego erudyty zwanego Cicero medicorum dla piękna jego łaciny ${ }^{29}$, w traktacie O sporządzaniu leków (Compositiones) Skryboniusza Largusa (1-50) ${ }^{30}$, w poradniku lekarskim $O$ medycynie (De medicina) opracowanym przez Kasjusza Feliksa (V wiek po Chrystusie) ${ }^{31}$. Nie wiemy, w jaki sposób Izydor wspomniane wiadomości zdobył. Czy znał powyższe dzieła bezpośrednio czy pośrednio? Czy też miał dostęp do innych źródeł, ustnych i pisanych, które nawiązywały do tejże tradycji? Korzystał przecież z licznych przeróbek, kompilacji, antologii, wyciągów, streszczeń, pism opracowanych przez mało znanych lub anonimowych autorów, które stanowiły podstawę ówczesnego wykształcenia, lecz nie zachowały się i pozostają nieznane ${ }^{32}$. Nawet urywki utworów Ojców Kościoła zdarzało mu się przytaczać na podstawie sporządzonych $\mathrm{z}$ nich florilegiów ${ }^{33}$. Nawiązania do Historii naturalnej (Naturalis historia) są rzadkie i niedosłowne, co pozwala przy-

26 Por. A. Ferraces Rodríguez, Isidoro de Sevilla y los textos de medicina, w: Isidorus medicus. Isidoro de Sevilla y los textos de medicina, red. A. Ferraces Rodríguez, A Coruña 2005, s. 21-25.

27 Por. M. von Albrecht, A History of Roman Literature from Livius Andronicus to Boethius, t. 2, Leiden 1997, s. 1477-1478.

28 Por. Ferraces Rodríguez, Isidoro de Sevilla y los textos de medicina, s. 17, 27.

29 Por. M. Cytowska - H. Szelest, Literatura rzymska. Okres cesarstwa, Warszawa 1992, s. 63.

30 Por. V. Nutton, Ancient Medicine, London 2013, s. 174-179.

31 Por. Nutton, Ancient Medicine, s. 4, 306. O zależności Izydora od jego pracy, zob. D. Gourevitch, Les maladies sous le regard du compilateur: métaphores végétales et animales, w: Isidorus medicus. Isidoro de Sevilla y los textos de medicina, red. A. Ferraces Rodríguez, A Coruña 2005, s. 191-192.

32 Por. J. Fontaine, Problèmes de méthode dans l'étude des sources isidoriennes, w: Isidoriana, red. M.C. Díaz y Díaz, León 1961, s. 115-131.

33 O historii takich zbiorów, por. J. de Ghellinck, Patristique et Moyen Âge. Études d'histoire littéraire et doctrinale, t. 2, Bruxelles 1961, s. 290-298. 
puszczać, że nie miał dostępu do odnośnych ksiąg encyklopedii (ks. 20-27: ziołolecznictwo, ks. 28-32: lekarstwa pochodzenia mineralnego i zwierzęcego), choć pisarze, których czytał, niewątpliwie znali dzieło Pliniusza ${ }^{34}$, toteż jest on w jego dziele wszechobecny ${ }^{35}$. Wiadomości o chorobach, ich profilaktyce i leczeniu Sewilczyk skrzętnie wybierał również z tekstów o innej tematyce, a mianowicie z klasycznej poezji (Wergiliusz) czy pism autorów chrześcijańskich (Kasjodora, Augustyna) ${ }^{36}$. Przekaz księgi czwartej Etymologii uzupełniają podane w księdze XVII informacje o właściwościach leczniczych roślin. Izydor zawdzięcza je lekturze wspomnianego utworu Gargiliusza Marcjalisa, a także łacińskich przekładów niezwykle poczytnego we wczesnym średniowieczu ${ }^{37}$ traktatu $O$ materii leczniczej

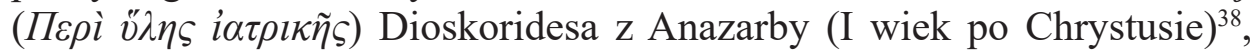
między innymi autorstwa Celiusza Aureliana oraz anonima zwanego Pseudo-Dioskoridesem (O ziołach kobiecych - De herbis femininis $)^{39}$.

\section{Izydor o zdrowiu}

Poglądy Izydora na zdrowie i chorobę bazują na teorii tetradowej (humoralnej) zapoczątkowanej przez Alkmeona z Krotonu (VI wiek przed Chrystusem), a następnie rozbudowywanej z wykorzystaniem nauki o czte-

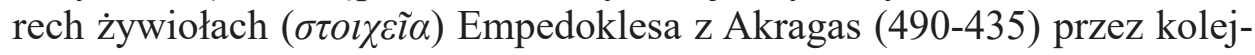

34 Por. Díaz y Díaz, Introducción, s. 195.

35 Por. M. Beagon, Variations on a Theme. Isidore and Pliny on Human and Human-Instigated Anomaly, w: Isidore of Seville and His Reception in the Early Middle Ages. Transmitting and Transforming Knowledge, red. A. Fear - J. Wood, Amsterdam 2016, s. 57.

36 Por. Isidorus, Etymologiae IV 6, 18 - Vergilius, Aeneis V 683; Isidorus, Etymologiae IV 10, 4 - Cassiodorus, Institutiones I 21; Isidorus, Etymologiae IV 7, 9 Augustinus, De Genesi ad litteram VII 18. O źródłach Izydora, por. J. Fontaine, Isidore de Séville et la culture classique dans l'Espagne wisigothique, t. 2, Paris 1959, s. 750-753, 812-813; Díaz y Díaz, Introducción, s. 194-195.

37 Por. P. Riché, Edukacja i kultura w Europie Zachodniej (VI-VIII wiek), tł. M. Radożycka-Paoletti, Warszawa 1995, s. 79-80.

38 O losach Dioskoridesa, jego pismach oraz ich recepcji, por. T.A. Osbaldestone, Introduction, w: Dioscorides. De materia medica. Being an herbal with many others medicinal materials, tł. T.A. Osbaldestone, Johannesburg 2010, s. XX-XXXVIII.

39 Por. A. Ferraces Rodríguez, La transmisión del „,De materia médica” en latín: de Dioscórides a Isidoro de Sevilla y algunos tratados de botánica, Santiago de Compostela 1996, s. 225-273. 
nych uczonych aż do Galena, w którego pismach znajdujemy jej w pełni rozwiniętą postać ${ }^{40}$. W Różnicach Izydor pisze mianowicie:

Jego [człowieka] ciało składa się z kości i mięsa, można w nim wyodrębnić cztery żywioły. Albowiem ma w sobie trochę ognia, powietrza, wody i ziemi. Ziemia jako element znajduje się w mięsie, woda - we krwi, powietrze w tchnieniu, ogień - w życiowym cieple ${ }^{41}$.

A w Etymologiach stwierdza:

1. Zdrowie to nienaruszony stan ciała i naturalna równowaga [wynikająca] $\mathrm{z}$ tego, co gorące (calido) oraz wilgotne (humido), czyli z krwi; stąd też pochodzi wyraz zdrowie (sanitas), w którym brzmi niejako „stan krwi” (sanguinis status). 2. Ogólną nazwą ,choroba” (morbi) obejmowane są wszystkie dolegliwości ciała; starożytni nazwali je chorobą (morbum) po to, aby samym słowem wskazać na moc śmierci (mortis vim), która w nich tkwi. [...] 3. Wszystkie choroby powstają z czterech płynów, to jest z krwi (ex sanguine) i żółci (felle), czarnej żółci (melancholia) i śluzu (flegmate). [...] 7. Te cztery płyny wywierają decydujący wpływ na zdrowych, one też wyrządzają krzywdę chorym. Albowiem gdy wykroczą poza ilość ustaloną przez naturę, powodują schorzenia ${ }^{42}$.

Po ukazaniu choroby jako stanu będącego wynikiem zaburzenia równowagi między płynami ustrojowymi Izydor podejmuje omówienie poszczególnych schorzeń, wśród których wyróżnia choroby wewnętrzne (zgodnie z przyjętymi w antycznej tradycji podziałami: ostre i przewlekłe ${ }^{43}$ ), czyli te, które cechuje ostry przebieg, gdyż „czy to szybko przechodzą, czy to natychmiast uśmiercają"44, oraz te, które cechuje przewlekły przebieg, po-

40 Por. A. Bednarczyk, Medycyna i filozofia w starożytności, Warszawa 1999, s. $102-$ 116; Turasiewicz, Pisma, s. 499.

41 Isidorus Hispalensis, Differentiae II 17. Zob. Isidorus Hispalensis, Etymologiae XI $1,16$.

42 Isidorus Hispalensis, Etymologiae IV 5.

43 Jak trafnie zauważa Ribémont (por. Les origines, s. 121), Izydor wprost nawiązuje do tytułów rozpraw Celiusza Aureliana: O chorobach majacych szybki, to jest ostry przebieg (De passionibus celeris vel acutis) oraz $O$ chorobach majacych wolny, to jest przewlekly przebieg (De passionibus tardis sive chronicis). Były one wyjątkowo popularne w średniowieczu. Zob. von Albrecht, A History of Roman Literature from Livius Andronicus to Boethius.

44 Por. Isidorus Hispalensis, Etymologiae IV 6, 1. 
nieważ „trwają przez długi czas”"45, a także nieznane w klasyfikacjach dokonanych przez wcześniejszych autorów ${ }^{46}$ choroby „zewnętrzne”, czyli te, które można zauważyć na powierzchni ludzkiego ciała (8), głównie dermatologiczne oraz takie, które mógł postrzegać jako dermatologiczne (zakaźne: zapalenie przyusznic/parotidae ${ }^{47}$; żółtaczka/hicteris ${ }^{48}$; onkologiczne: rak skóry/cancer) ${ }^{49}$, a ponadto wady wzroku (kurza ślepota/nyctalmos) $)^{50}$. O ile kompozycja księgi zdradza, jak widzimy, przemyślenie materiału oraz odzwierciedla dokonane przez Sewilczyka klasyfikacje, zawartość poszczególnych rozdziałów przypomina naprędce sporządzone, chaotyczne, nieuporządkowane notatki ${ }^{51}$. Układ materiału jest uderzająco dowolny: Izydor nie omawia schorzeń w porządku alfabetycznym, nie wprowadza też podziałów, przyjmując za punkt wyjścia narządy i układy, które porażają. Dopuszcza się powtórzeń i nieścisłości: zapalenie płuc (peripleumonia) omawia jako schorzenie, któremu towarzyszy gwałtowny ból i duszność wśród chorób ostrych, a następnie jako obrzęk płuc z pluciem krwawą pianą wśród przewlekłych ${ }^{52}$; satiriasis to nazwa priapizmu oraz choroby skórnej, która prowadzi do powstania skupisk brodawek ${ }^{53}$. Podobnie jak pozostawienie pustego hasła ,przetoka” (syringio), wymienione zjawiska dowodzą nieukończenia Etymologii ${ }^{54}$.

W rozdziale VI (De acutis morbis) Izydor prezentuje 16, w rozdziale VII (De chronicis morbis) - 42, w rozdziale VIII (De morbis qui in superficie corporis videntur) - 26 dolegliwości. Zauważmy, że niektóre spośród opisanych schorzeń stanowią raczej objawy, które mogą towarzyszyć rozmaitym chorobom, niż rzeczywiste jednostki nozologiczne. Są to na przykład gorączka (febris) ${ }^{55}$, ból głowy $(\text { cephalea })^{56}$, zimne

45 Por. Isidorus Hispalensis, Etymologiae IV 7, 1.
46 Zwraca na to uwagę: Gourevitch, Les maladies, s. 178.
47 Por. Isidorus Hispalensis, Etymologiae IV 8, 2.
48 Por. Isidorus Hispalensis, Etymologiae IV 8, 13.
${ }_{49}$ Por. Isidorus Hispalensis, Etymologiae IV 8, 14.
${ }_{50}$ Por. Isidorus Hispalensis, Etymologiae IV 8, 8.
51 Wbrew Ribémontowi (Les origines, s. 123), który w sposób nieuzasadniony stwierdza, że cały wykład Izydora o chorobach jest dobrze przemyślany i rzetelnie usystematyzowany.

52 Por. Isidorus Hispalensis, Etymologiae IV 6, 9; IV 7, 15.

53 Por. Isidorus Hispalensis, Etymologiae IV 7, 34; IV 8, 9.

54 Por. Isidorus Hispalensis, Etymologiae IV 8, 22. O tym, jak powstawały Etymologie, pisze Elfassi. Por. Elfassi, Isidore, s. 245-249.

55 Por. Isidorus Hispalensis, Etymologiae IV 6, 2.

56 Por. Isidorus Hispalensis, Etymologiae IV 7, 2. 
dreszcze $(\text { typi })^{57}$, zachrypnięcie (raucedo $)^{58}$, plucie krwią (haemopto$i s)^{59}$, trudności z oddawaniem moczu (stranguria) ${ }^{60}$, rozwolnienie (diarria $)^{61}$, bąbel (pustula $)^{62}$, blizna (cicatrix) ${ }^{63}$. Ostrą niedrożność jelitową Izydor przedstawia jako silny ból jelit, sprowadzając schorzenie, które może prowadzić do powstania stanu zagrażającego życiu, do jednego z symptomów towarzyszących zakłóceniom funkcjonowania układu trawiennego (ileos) $)^{64}$.

Jak zauważa Mirko Grmek, podczas gdy współczesna diagnostyka usiłuje dojść do ukrytych w ludzkim ciele zmian chorobowych, które objawiają się pewnymi symptomami, diagnostyka starożytna polegała przede wszystkim na stwierdzeniu symptomów $w^{65}$. Wypowiedź badacza znajduje potwierdzenie także w analizowanym tekście. Encyklopedysta wyjątkowo rzadko zastanawia się nad etiologią chorób: obłęd (phrenesis) powstaje pod wpływem żółci ${ }^{66}$, epilepsję powoduje uciskający mózg nadmiar czarnej żółci67, rwa kulszowa (sciasis) to skutek nagromadzenia wokół kości śluzu ${ }^{68}$, dotkniętych katarem przeziębionych (coryza) nęka kichanie spowodowane spływaniem śluzu z głowy do nosa ${ }^{69}$. Niekiedy opisuje okoliczności powodujące powstanie stanów chorobowych czy sprzyjające ich rozwojowi. Czytamy, że wyniszczenie (cacexia) może być skutkiem nieumiarkowania chorego, niewłaściwego stosowania leków bądź zbyt długiej rekonwalescencji ${ }^{70}$, gruźlica (phtisis) często dotyka młodych ${ }^{71}$, atak

\footnotetext{
57 Por. Isidorus Hispalensis, Etymologiae IV 7, 10.

58 Por. Isidorus Hispalensis, Etymologiae IV 7, 14.

59 Por. Isidorus Hispalensis, Etymologiae IV 7, 16.

60 Por. Isidorus Hispalensis, Etymologiae IV 7, 33.

61 Por. Isidorus Hispalensis, Etymologiae IV 7, 35.

62 Por. Isidorus Hispalensis, Etymologiae IV 8, 20.

63 Por. Isidorus Hispalensis, Etymologiae IV 8, 23.
}

64 Por. Isidorus Hispalensis, Etymologiae IV 6, 14. Zob. Scribonius Largus, Compositiones 116: „[...] ileon quod vitium est inflatio tenuium intestinorum”; Celsus, De medicina II 1, 8: „tenuioris intestini morbus quem ileon vocant”. Identyfikacja choroby za: Bednarczyk, Medycyna, s. 479 .

65 Por. M. Grmek, Historia chorób u zarania cywilizacji zachodniej, tł. A.B. Matusiak, Warszawa 2002, s. 8-10.

$\begin{array}{ll}{ }_{66} & \text { Por. Isidorus Hispalensis, Etymologiae IV 6, } 3 . \\ { }_{67} & \text { Por. Isidorus Hispalensis, Etymologiae IV 7, } 5 . \\ { }_{68} & \text { Por. Isidorus Hispalensis, Etymologiae IV 7, } 29 . \\ 69 & \text { Por. Isidorus Hispalensis, Etymologiae IV 7, } 12 . \\ { }_{70} & \text { Por. Isidorus Hispalensis, Etymologiae IV 7, } 26 . \\ { }_{71} & \text { Por. Isidorus Hispalensis, Etymologiae IV 7, } 17 .\end{array}$ 
serca (cardia) powoduje ból i strach ${ }^{72}$, posoka (sanies) zaś powstaje z krwi, którą wydziela rana pod wpływem ciepła ${ }^{73}$. Sewilczyk skupia się głównie na przebiegu chorób. Ukazuje wybrane objawy w sposób precyzyjny i zrozumiały, ale całość jest niewystarczająca do zdiagnozowania dolegliwości, co po raz kolejny dowodzi, że adresatem Etymologii był ciekawy świata erudyta, którego encyklopedysta wprowadzał w świat medycyny, a nie me$\mathrm{dyk}^{74}$. A zatem spowodowanemu strachem czy bólem atakowi serca towarzyszy przeraźliwy lęk ${ }^{75}$, objawy zapalenia opłucnej (pleurisis) to ostry ból w boku, gorączka i plucie krwią ${ }^{76}$, gruźlica polega na powstawaniu w płucach wrzodów i obrzęku ${ }^{77}$. Czytając opis tężca (tetanus), możemy odnieść wrażenie, że mamy do czynienia z chorobą układu ruchu, gdyż zdaniem pisarza jest on jedynie: ,silniejszym [niż w przypadku zwykłych spazmów, opisanych wyżej] skurczem mięśni, [które biegną] od szyi do pleców"78.

Niekiedy odnosimy wrażenie, że autor sam ma wątpliwości co do przebiegu schorzenia, które opisuje: „Kurza ślepota (nyctalmos) to dolegliwość, która w dzień, mimo otwartych oczu, odejmuje wzrok, lecz przywraca go po tym, gdy zapadną ciemności, czy też na odwrót, jak twierdzi większość: za dnia się widzi, a w nocy nie"'79.

\section{Od nazwy schorzenia do jego opisu}

W swojej encyklopedii Izydor zamierza opowiedzieć o świecie, wyjaśniając znaczenie opisujących go słów. Jest bowiem przekonany, że poznanie początków słów prowadzi do poznania nazywanych przez nie rzeczy ${ }^{80}$. Pisze

72 Por. Isidorus Hispalensis, Etymologiae IV 6, 4. W cytowanym wydaniu: cardia $<c a>$. Przyjmuję cardia za: A. Ferraces Rodríguez, Aspectos léxicos del libro IV de las „Etimologías” en manuscritos médicos altomedievales, w: Isidorus, red. A. Ferraces Rodríguez, A Coruña 2005, s. 106-107.

73 Por. Isidorus Hispalensis, Etymologiae IV 8, 22.

74 Zwraca na to uwagę: Ferraces Rodríguez, Isidoro de Sevilla y los textos de medicina, s. 14.

75 Por. Isidorus Hispalensis, Etymologiae IV 6, 4.

76 Por. Isidorus Hispalensis, Etymologiae IV 6, 8.

77 Por. Isidorus Hispalensis, Etymologiae IV 7, 17.

78 Isidorus Hispalensis, Etymologiae IV 6, 12. Opis tężca i jego leczenia, por. Celsus, De medicina IV 6.

79 Isidorus Hispalensis, Etymologiae IV 8, 8.

80 Por. J. Fontaine, Isidore de Séville. Genèse et originalité de la culture hispanique au temps de Wisigoths, Turnhout 2001, s. 283-296. 
Etymologia to badanie pochodzenia wyrazów, w trakcie którego uzyskujemy znaczenie słowa czy imienia przez jego wyjaśnienie. [...] Otóż gdy zobaczysz, skąd wywodzi się słowo, szybciej zrozumiesz jego znaczenie. Dzięki etymologii poznanie wszelkiej rzeczy staje się łatwiejsze ${ }^{81}$.

Również wprowadzając czytelnika w arkana medycyny, poszukuje początków słów, którymi ta dyscyplina operuje, przyjmując za podstawę definicji terminów ich źródłosłowy ${ }^{82}$. W rozdziałach VI-VII podawane przez niego główne (to jest pierwsze, a często jedyne) nazwy schorzeń z reguły stanowią kalki nazw greckich. Wyjątkami są febris (gorączka), telum (przenikający ból w boku), pestilentia (pomór), raucedo (zachrypnięcie), suspirium (astma), calculus petrae (kamica) ${ }^{83}$. W rozdziale VIII wśród nazw głównych przeważają łacińskie (18 przypadków), co, jak się wydaje, może wynikać z większego oswojenia z chorobami dermatologicznymi: są one widoczne i przez to łatwiejsze do zdiagnozowania, a ponadto mniej groźne dla życia, toteż często rozpoznawali je i leczyli amatorzy posługujący się, w odróżnieniu od mówiących po grecku lekarzy ${ }^{84}$, łaciną. Wyjaśnienie pochodzenia nazw greckich Sewilczyk często sprowadza do ich przetłumaczenia:

Zapalenie wątroby (hepaticus morbus) otrzymało nazwę od dolegliwości wą-

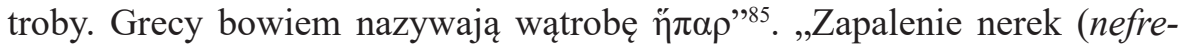
sis) otrzymało nazwę od schorzenia nerek. Grecy bowiem mówią na nerki

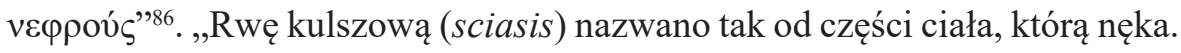
Otóż kości biodrowe, których górny brzeg sięga tam, gdzie zaczynają się jelita, Grecy zwą i $\sigma \chi^{i} \alpha^{87}$.

Galen zauważa, że nazwa jednostki nozologicznej może nawiązywać do chorej części ciała, głównego objawu czy przyczyny schorzenia, jak

81 Isidorus Hispalensis, Etymologiae I 29, 1-2.

82 Jak trafnie ujmuje to: Elfassi, Isidore, s. 258.

83 Por. Isidorus Hispalensis, Etymologiae IV 6, 2.13.17-19; 7.14.32.

84 Por. H.-I. Marrou, Historia wychowania w starożytności, tł. S. Łoś, Warszawa 1969, s. 356-357, 368; M.L. Clarke, Higher Education in the Ancient World, London 1971, s. 109-110.

85 Isidorus Hispalensis, Etymologiae IV 7, 21.

86 Isidorus Hispalensis, Etymologiae IV 7, 24.

87 Isidorus Hispalensis, Etymologiae IV 7, 29. Starożytni postrzegali newralgię nerwu kulszowego jako bóle w stawie biodrowym. Por. Grmek, Historia, s. 19; Langslow, Medical, s. 486. 
również do imienia pierwszego lekarza, który ją wyleczył, czy słynnego chorego, którego nękała. Może też odzwierciedlać podobieństwo zachodzące między jej symptomami a zjawiskami otaczającego świata ${ }^{88}$. Wyjaśniając pochodzenie nazw prezentowanych schorzeń, Sewilczyk potwierdza słuszność obserwacji wielkiego uczonego. Wskazuje dotknięty chorobą narząd: „Utrata głosu (branchos) to zapalenie gardła spowodowane zimną wilgocią. Grecy nazywają bowiem gardło $\beta \rho \alpha ́ \gamma \chi 0 \varsigma ~[. .] " 89$, nawiązuję do ich przebiegu: „Plucie krwią (haemoptois) to wydalanie krwi przez usta, skąd też wywodzi się jego nazwa. Na krew mówią bowiem Grecy $\alpha \tilde{i} \mu \alpha{ }^{\prime 90}$, przyczyn: „Choroba czarnej żółci ${ }^{91}$ (melancolia) została tak nazwana z powodu czarnej żółci. Czarny bowiem to po grecku $\mu \varepsilon^{\prime} \lambda \alpha v$, zaś

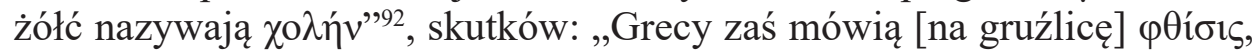
ponieważ prowadzi do wycieńczenia całego ciała"93. Posługuje się metaforami odsyłającymi czytelnika do świata natury:

Łysina (alopicia) to wypadanie włosów, które następuje po tym, jak owłosienie przybierze rudą barwę przypominającą [kolor] miedzi. Nazwę tę otrzymała dla podobieństwa do zwierzęcia, [a mianowicie] lisa, którego Grecy zwą $\dot{\alpha} \lambda \omega ́ \pi \varepsilon \kappa \alpha^{94}$.

Jęczmień (ordeolus) to bardzo mała i ropiejąca opuchlizna, która powstaje między włoskami na powiekach. W środku szeroka, na końcach zwężająca

88 Por. Galenus, De methodo medendi II 2.

89 Isidorus Hispalensis, Etymologiae IV 7, 13.

90 Isidorus Hispalensis, Etymologiae IV 7, 16.

91 Melancholią w czasach nowożytnych nazwano permanentny smutek, przygnębienie, depresję. Por. J. Scarborough, Medical Terminologies: Classical Origins, Oklahoma 1992, s. 219. Jednak dla starożytnych był to stan, któremu towarzyszyły również wybuchowość (G.S. Kirk - G.E. Raven - M. Schofield, Filozofia przedsokratejska, tł. J. Lang, Poznań 2009, s. 187), strach, szał, niechęć do ludzi oraz inne, bardzo różne objawy (R. Klibansky - E. Panofsky - F. Saxl, Saturn and Melancholy. Studies in the History of Natural Philosophy, Religion and Art, Nendeln 1979, s. 14-55). Dlatego thumaczę nazwę schorzenia w oparciu o pracę Langslow (Medical, s. 487: „,black-bile disease”). Na uwagę zasługuje artykuł: J. Pigeaud, De la mélancolie et de quelques autres maladies dans les „Étymologies” d'Isidore de Séville (opublikowany w pracy zbiorowej Textes médicaux latins antiques, red. G. Sabbah, Saint-Étienne 1984, s. 87-109), z którym niestety nie miałam możliwości zapoznania się.

92 Isidorus Hispalensis, Etymologiae IV 7, 9.

93 Isidorus Hispalensis, Etymologiae IV 7, 17.

94 Isidorus Hispalensis, Etymologiae IV 8, 1. O tym, jak wyjaśniają nawiązującą do lisa nazwę tej choroby inni pisarze medycy, pisze: Gourevitch, Les maladies, s. 184-185. 
się, przypomina ziarno jęczmienia (hordei granum), od którego też otrzymała nazwę $e^{95}$.

Zajady (frenusculos) to owrzodzenia otaczające kąciki ust, podobne do tych, które powstają u zwierząt pociągowych pod wpływem chropowatych wędzideł (frenorum $)^{96}$.

Niektóre wywody etymologiczne są wyjątkowo obrazowe:

Kolka (telum) [dosł. „ostra broń”] to ból w boku. Lekarze nazwali ją tak, dlatego że przeszywa ciało bólem niczym miecz (gladius) ${ }^{97}$.

Czyrak mnogi (carbunculus) otrzymał swą nazwę, ponieważ na początku jest czerwony jak ogień, potem czarny jak węgiel (carbo), który wygasł ${ }^{98}$.

Omdlenie (scothomia) zawdzięcza swą nazwę objawowi polegającemu na tym, że oczy nagle spowija mrok, czemu towarzyszy odczucie wirowania. Wir z kolei powstaje, ilekroć wiatr wzmaga się oraz wzbija kłębiący się kurz. Podobnie w arteriach i żyłach, które znajdują się w czubku głowy człowieka, wskutek uwolnienia wilgoci tworzy się bańka powietrza (ventositas), [w związku z czym] następuje zamazanie widzenia. Stąd też mówimy o odczuciu wirowania (vertigo) ${ }^{99}$.

Na uwagę zasługują ustępy, w których Izydor poszukuje początków greckich nazw chorób, odwołując się zarówno do znaczenia spokrewnionych z nimi wyrazów greckich, jak też do skojarzeń słuchowych, które powstają u słyszącej je osoby łacińskojęzycznej:

Obłęd (phrenesis) nazwano tak czy to dlatego, że krępuje umysł - Grecy bowiem mówią na umysł $\phi \rho \varepsilon ́ v \alpha \varsigma$ - czy też dlatego, że [chorzy] zgrzytają zębami (infrendant), gdyż „wić się w szale” (frendere) to tyle co „miażdżyć zębami”

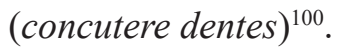

95 Isidorus Hispalensis, Etymologiae IV 8, 16. Zakażenie gruczołów powiek zwali jęczmieniem (hordeolus, hordeolum, hordiolum) również inni łacińscy autorzy. Por. Gourevitch, Les maladies, s. 181-182. Marcellus z Burdigali, chcąc leczyć podobne podobnym, zalecał też kurację dziewięcioma ziarenkami jęczmienia. Por. Marcellus, De medicamentis liber VIII 192.

96 Isidorus Hispalensis, Etymologiae IV 8, 18.

97 Isidorus Hispalensis, Etymologiae IV 6, 13.

98 Isidorus Hispalensis, Etymologiae IV 6, 16.

99 Isidorus Hispalensis, Etymologiae IV 7, 3.

100 Isidorus Hispalensis, Etymologiae IV 6, 3. 
Grecy mówią, że podagra (podagram) otrzymała taką nazwę, gdyż krępuje stopy, a także z powodu dzikiego (ferali) bólu, [który powoduje]. W rzeczy samej o wszystkim, co jest zbyt bezlitosne, posługując się przenośnią, mówimy „dzicz” (agreste) ${ }^{101}$.

Zauważmy, że przytoczona wypowiedź jest niezrozumiała dla kogoś, kto nie zna greki, gdyż Izydor nie tłumaczy, że podagryczny ból kojarzo-

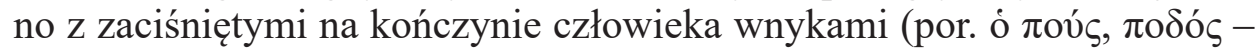
'noga', $\dot{\eta} \alpha$ $\gamma \rho \alpha$ - 'wnyki'). Jak się wydaje, Sewilczyk mógł zaczerpnąć swe wyjaśnienie z jakiegoś źródła, które nie podawało znaczenia powyższych greckich wyrazów, toteż sam nie rozumiał źródłosłowu tej nazwy.

Prezentując niektóre dolegliwości, Izydor wymienia także ich nazwy oboczne: łacińskie obok greckich, greckie obok łacińskich, łacińskie obok łacińskich. Podanie synonimicznych nazw mogło, jak się wydaje, ułatwiać czytelnikowi przyporządkowanie ukazywanych objawów do dolegliwości znanej mu jedynie z nazwy. Ponadto służyło ono pełniejszej prezentacji schorzenia, gdyż kolejne nazwy rzadko odnoszą się do tych jego cech, które odsłania nazwa podstawowa. Czytamy:

Epilepsja (epilemsia) otrzymała [swą] nazwę, ponieważ to, co powstrzymuje mózg [chorego], równocześnie opanowuje także ciało. Grecy zaś nazywają

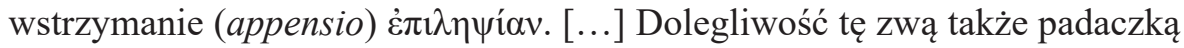
(caduca), dlatego że chory pada (cadens) i męczy się w konwulsjach. Ludzie zwą ich [epileptyków] również lunatykami (lunaticos), gdyż złe duchy zastawiają na nich zasadzki w zależności od krążenia księżyca (luna). Podobnie [mówi się o nich] dręczeni (larvatici) [por. larva - 'zły duch, upiór']. Choroba, która opanowuje lunatyków, zwana jest także komicjalną (comitialis) [...], ponieważ u pogan przerywano komicja, jeśli w dniu, gdy odbywały się, ktoś dostawał ataku ${ }^{102}$.

Grecy nazwali żółtaczkę hicteris od nazwy pewnego zwierzęcia, które ma kolor żółci ${ }^{103}$. Latynowie mówią na tę chorobę tęczowa (arcuatum) dla podobieństwa [skóry chorego] do tęczy (arcus caelestis). Warron natomiast po-

101 Isidorus Hispalensis, Etymologiae IV 7, 30.

102 Isidorus Hispalensis, Etymologiae IV 5-7.

103 Pliniusz podaje, że to ptak o żółtym umaszczeniu zawdzięcza swą nazwę (,ptak żółtaczkowy", avis hicterus) nazwie choroby. Zgodnie z rozpowszechnionym przekonaniem wystarczy raz popatrzeć na ptaka, by wyzdrowieć z żółtaczki, przy czym ptak wtedy umiera. Zdaniem encyklopedysty rdzenna łacińska nazwa ,żółtaczkowego ptaka” to galgalus, czyli trznadel. Por. Plinius, Naturalis Historia XXX 28, 94. 
wiada, że zowią ją złocistą chorobą (auriginem), gdyż [skóra chorego przybiera] złoty kolor. Nazwano ją również chorobą królewską (regium morbum), ponieważ, jak się uważa, szybko można się z niej wyleczyć dobrym winem oraz potrawami godnymi królewskiego podniebienia (regalibus cibis) ${ }^{104}$.

Jeszcze bardziej wyczerpujące opisy powstają wówczas, gdy Sewilczyk uzupełnia dyskursy etymologiczne prezentacją właściwości schorzeń niezwiązanych z ich nazwami. Na przykład:

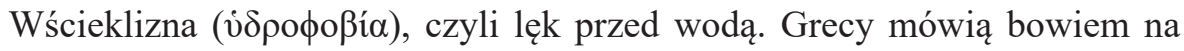

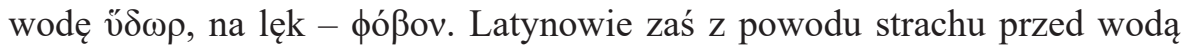
[który wywołuje] nazywają tę chorobę wodowstrętową (lymphaticum). Powstaje zaś po ukąszeniu przez wściekłego psa czy też ze śliny wyplutej na ziemię: gdy człowiek czy zwierzę jej dotknie, wypełnia go szaleństwo czy opanowuje wścieklizna ${ }^{105}$.

\section{Pomór, zaraza, morowe powietrze}

Najbardziej obszerny opis (11 linijek w cytowanym wydaniu) Izydor poświęca pomorowi:

Pomór (pestilentia) to zaraza (contagium), która, skoro opanuje jednego, szybko przechodzi na wielu. Powstaje zaś z niezdrowego powietrza oraz dosięga wnętrzności, do których się wślizguje. Najczęściej dochodzi do niej z powodu właściwości powietrznych mas, jednakże wybucha jedynie na mocy wyroku Wszechmogącego Boga. A nazwano ją pestilentia niejako [nawiązując do] pastulentia [por. pascor, pasci, pastus sum - 'paść się, żywić się, zjadać'], gdyż pochłania [wszystko] niczym pożar, jak [czytamy]: „Zakaźna choroba (pestis) zstępuje na całe ciało"106. [Zwana] również zarazą (contagium) od dotykania (a contingendo), ponieważ zakaża każdego, który ma [z nią] styczność. [Mówią] też [na nią] podbrzuszyna (inguina) [por. inguen, inguinis - 'niższa część brzucha, pachwina'], ponieważ uderza w podbrzusze (ab inguinum percussione) ${ }^{107}$. Zwana także morowym powietrzem (lues) od

104 Isidorus Hispalensis, Etymologiae IV 8, 13.

105 Isidorus Hispalensis, Etymologiae IV 6, 15.

106 Por. Vergilius, Aeneis V 683.

107 Zdaniem niektórych badaczy inguina Izydora to dżuma. Por. I. García García M. Ramos Cobos - E. Gozalbes Cravioto, Enfermedad y Cuidados en la Obra de Isidoro 
zguby (a labe) i żałoby (luctu), gdyż jest tak gwałtowna, że nie daje czasu, by spodziewać się życia czy śmierci, lecz [powoduje] nagłe osłabienie [wraz z którym] nadchodzi śmierć ${ }^{108}$.

Zasługuje na uwagę obszerność i barwność tej relacji. Składa się na nią 5 dyskursów etymologicznych, wywód dotyczący naturalnych i nadprzyrodzonych przyczyn schorzenia oraz opis jego przebiegu. Cytat z Eneidy oraz autocytat ${ }^{109}$ sąsiadują z ludową nazwą choroby (inguina) oraz wynalezionym przez encyklopedystę wyrazem pastulentia, który - jak zauważa Danielle Gourevitch - brzmi niczym zabawny makaronizm ${ }^{110}$. Takie dopracowanie analizowanego passusu może świadczyć o tym, że ze względu na tragiczność ich skutków dla wielkich grup ludności pomory były w odczuciu Izydora najgroźniejszymi spośród chorób ${ }^{111}$. Słuszność tego przypuszczenia potwierdza rozdział XXXIX traktatu $O$ naturze rzeczy (De rerum natura) ${ }^{112}$. Sewilczyk ukazuje w nim pomór jako chorobę, która dotyka cały kosmos, gdy

moc suszy czy gorąca, czy też nadmiar deszczy prowadzi do tego, że powietrze się psuje [...] zaburzona zostaje naturalna równowaga, żywioły doznają

de Sevilla, „Index de Enfermería” 14/51 (2005) s. 72. Wśród licznych epidemii średniowiecznych wyróżniały się dwie fale „,czarnej śmierci”, tj. pandemie dżumy w odmianie płucnej i gruczołowej, które rozpętały się za Justyniana (541-543) oraz w XIV wieku. Por. J. Le Goff, Kultura średniowiecznej Europy, t1. H Szymańska-Grossowa, Warszawa 1970, s. 447; Z. Gliński - K. Grzegorczyk, Dżuma nadal jedna z najniebezpieczniejszych chorób, „Życie Weterynaryjne” 94/1 (2019) s. 18-19.

108 Isidorus Hispalensis, Etymologiae IV 6, 17-19.

109 Por. Isidorus Hispalensis, Etymologiae IV 6, 19: „[...] non habeat spatium temporis quo aut vita speretur aut mors, sed repentinus languor simul cum morte venit" - De rerum natura 39, 1: ,haec enim aegritudo non habet spatium temporis quo aut vita speretur aut mors, sed repentinus languor simul cum morte venit". O autocytatach w pismach Izydora, por. Ferraces Rodríguez, Isidoro, s. 25-26.

110 Por. Gourevitch, Les maladies, s. 193.

111 Pomory były nieodłączną częścią życia feudalnych społeczności. Wybuchały one również na Półwyspie Iberyjskim. Por. W. Kowalski, Biskup krakowski Marcin Szyszkowski a konsekwencje zarazy lat dwudziestych XVII stulecia, w: Człowiek i przyroda w średniowieczu $i$ we wczesnym okresie nowożytnym, red. W. Iwańczak - K. Bracha, Warszawa 2000, s. 227; M. Sotomayor y Muro, La Iglesia en la España Romana, w: Historia de la Iglesia en España, t. 1, red. R. García Villoslada, Madrid 1979, s. 393; T. González, La Iglesia desde la conversión de Recaredo hasta la invasión árabe, w: Historia de la Iglesia en España, t. 1, red. R. García Villoslada, Madrid 1979, s. 572; R. Collins, Visigothic Spain 409-711, Oxford 2004, s. 110.

112 O piśmie, por. Ledzińska, Gramatyka, s. 64-69. 
skażenia, powietrze się psuje, powstaje niosący zarazę powiew i nadchodzi zguba, która poraża ludzi oraz wszystkie istoty żywe ${ }^{113}$.

W Historii ${ }^{114}$ porównuje do zarazy zgubne nauki heretyków, pisząc, że cesarz Walens, pod wpływem którego Goci przyjęli arianizm, wprysnął w swój lud „śmiercionośny zarodek trującej zarazy” („virus pestiferum semine pernicioso transfudit" ${ }^{115}$, a także zachłanność króla Leowigilda, który przejął na rzecz państwa dobra osób prywatnych i kościelne majątki (,labes [...] fisco associaverat") $)^{116}$.

Izydor zauważa, że zaraza czyha na człowieka wszędzie: w ziemi i w wodzie ${ }^{117}$, a przede wszystkim w powietrzu. Jej zarodki (pestifera semina) wędrują na znaczną odległość - roznoszą je wiatry, z deszczem wylewają chmury. Zakażenie przebiega na dwa sposoby: poprzez spożywanie zakażonych plonów ziemi oraz przez wdychanie zarazków unoszących się w powietrzu. Choroba prowadzi do powstania szpetnych wrzodów (ulceribus taetris) czy zadaje gwałtowny cios (subita percussione), uśmiercając niedomagające ciało (languescens morbo corpus) ${ }^{118}$.

\section{Izydor o leczeniu i pielęgnacji chorych}

Jak widzimy, Sewilczyk umieszcza pomór w porządku natury i przedstawia przyczynowo-skutkowe wyjaśnienie jego powstania i przebiegu. Wprawdzie z mocą podkreśla, że wybucha on jedynie w wyniku dopustu Bożego ${ }^{119}$, jest karą za ludzką niegodziwość ${ }^{120}$, a gdzie indziej zauważa, że sprawcami chorób w ogóle mogą być złe duchy (,daemones [...] spiritus impuri $[\ldots]$ morbos inferunt") ${ }^{121}$. Stwierdzenia te nie stoją w sprzeczno-

113 Isidorus Hispalensis, De rerum 39, 1.

114 Por. Ledzińska, Gramatyka, s. 82-85.

115 Isidorus Hispalensis, Historia de regibus Gothorum, Wandalorum et Sueborum 7. O arianizacji Wizygotów, por. J. Strzelczyk, Goci-rzeczywistość i legenda, Warszawa 1984, s. 104-109.

116 Por. Isidorus Hispalensis, Historia 55. O antyarystokratycznych posunięciach króla, por. Strzelczyk, Goci, 210-211.

117 Por. Isidorus Hispalensis, Differentiae I 143: „Pestilentiae autem tres modi sunt: aut ex terra, aut ex aqua, aut ex aere".

118 Por. Isidorus Hispalensis, De rerum 39, 1-2.

119 Por. Isidorus Hispalensis, Etymologiae IV 6, 17.

120 Por. Isidorus Hispalensis, De rerum 17, 4.

121 Por. Isidorus Hispalensis, Differentiae II 14, 8-12. 
ści z tym, że podchodzi do tego oraz innych schorzeń racjonalnie: stanowczo stwierdza, że nie powinno się lekceważyć pomocy medyków oraz odwołuje się do autorytetu znakomitych biblijnych bohaterów, którzy podawali schorowanym leki: „Nie należy pogardzać środkami leczniczymi, które oferuje medycyna. Pamiętamy przecież, że Izajasz ofiarował jakiś lek niedomagającemu Ezechiaszowi, apostoł Paweł zaś powiedział, że Tymoteuszowi pomoże odrobina wina" ${ }^{122}$ (por. Iz 38,21; 1Tm 5,23), aczkolwiek potrafili uzdrawiać także, dokonując cudów, o czym Sewilczyk opowiada w traktacie $O$ narodzinach $i$ śmierci świętych ojców ${ }^{123}$, którego laudacyjna wymowa każe mu skupiać uwagę na nadprzyrodzonych zdolnościach oraz niezwykłych dokonaniach bohaterów ${ }^{124}$ :

Jak wiadomo, [Paweł] dokonał następujących cudów. Porwany, wstąpił do trzeciego nieba (2Kor 12,2-4), ukarał zwodniczego ducha Pytona, nakazując mu, aby odszedł (Dz 15,16-21), na nowo tchnął ducha życia w zmarłego młodzieńca (Dz 20,9-12); poraził ślepotą maga (Dz 13,6-11), chromemu przywrócił sprawny chód (Dz 14,8-10), ukąszenia okrutnej żmii ani nie poczuł, ani się nie lękał, lecz wrzucił [ją] do ognia, by spłonęła (Dz 28,1-6), ponadto modląc się, uzdrowił z gorączki ojca Publiusza (Dz 28,8) ${ }^{125}$.

Izydor przyjmuje za swoimi poprzednikami podział sposobów leczenia na farmakologiczne, chirurgiczne oraz dietetyczne ${ }^{126}$. Jak widzimy, kolejność, w której je podaje, odbiega od tradycyjnej (dietetyka, farmakologia, chirurgia ${ }^{127}$. Być może jest to skutek niedopracowania (w dalszej części rozdziału Izydor omawia je w kanonicznej kolejności), być może wynika z chęci wyeksponowania zabiegów, których stosowanie stanowiło domenę fachowców, podczas gdy praktyki dietetyczne, polegające zdaniem starożytnych nie tylko na zdrowym odżywianiu się, lecz na „dotrzymywaniu się [zdrowego] sposobu życia" ${ }^{128}$ w ogóle, były dostępne ogółowi czytelni-

122 Isidorus Hispalensis, Etymologiae IV 9, 1.

123 Por. Ledzińska, Gramatyka, s. 57-59.

124 Por. T. Krynicka, Izydora z Sewilli „O narodzinach i śmierci świętych ojców”: kompozycja traktatu, VoxP 73 (2020) s. 101, 106.

125 Isidorus Hispalensis, De ortu et obitu patrum 68, 2-3.

126 Por. Isidorus Hispalensis, Etymologiae IV 9, 2-3.

127 Por. Celsus, De medicina, Prooemium 9: „In tres partes medicina diducta est, ut una esset quae victu, altera quae medicamentis, tertia quae manu mederetur. Primam

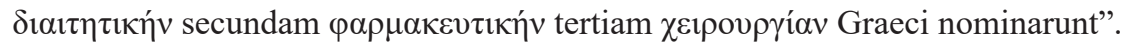

128 Isidorus Hispalensis, Etymologiae IV 9, 2. 
ków. O tym, jak wyglądała właśnie taka, niefachowa opieka nad chorymi, dowiadujemy się z Izydorowej Reguły (Regula monachorum). W tym skierowanym do mnichów klasztoru sewilskiego piśmie ${ }^{129}$ Sewilczyk stwierdza, że ukrywanie dolegliwości jest równie niedopuszczalne co udawanie, że jest się chorym. Dotknięty niemocą członek wspólnoty ma wyjawić nękającą go chorobę, współbracia zaś powinni otaczać go czułą opieką (humaniusque tractentur). Chorujących powierzano opiece zdrowego, wyróżniającego się świętością obyczajów mnicha. Jak widzimy, Izydor nie wymaga, by posiadał on specjalistyczne przeszkolenie: lekarzy było mało, ich usługi były kosztowne i dostępne niewielu ${ }^{130}$. Mówi natomiast o troskliwości i zapobiegliwości infirmera, który miał czynić wszystko, by zaspokoić potrzeby niedomagających ${ }^{131}$. Opisuje więc $\mathrm{w}$ istocie nie leczenie, ale pielęgnację chorych. Umieszczano ich w osobnym, cichym pomieszczeniu (locus aegrotantium) $)^{132}$. Zapewniano im lekkostrawne pożywienie (delicatiora alimenta) ${ }^{133}$, m.in. chleb lepszej jakości, wypiekany przez pracujących w klasztorze świeckich ${ }^{134}$, mogli również posilać się poza ustalonymi posiłkami ${ }^{135}$, podczas gdy czyniącym to osobom zdrowym Izydor zarzucał obżarstwo ${ }^{136}$. Byli zwalniani z obowiązkowych prac i postów ${ }^{137}$, podobnie jak starsi mnisi za zgodą opata mogli zamieszkać w osobnej celi ${ }^{138}$; wydatki na potrzeby chorych finansowano w pierwszej kolejności ${ }^{139}$. Sewilczyk stwierdza, że zdrowym mnichom nie wolno gorszyć się z powodu łagodniejszego traktowania chorych braci ${ }^{140}$, mają ich wspierać i podtrzymywać (tolerare). Z drugiej strony ma świadomość, że w niedomagających zagnieździć się może pycha, chciwość, szukanie ciele-

129 Por. Ledzińska, Gramatyka, s. 80-82.

130 Zwraca na to uwagę: P.C. Díaz, Teoría y práctica de la medicina visigoda. Del enciclopedismo de Isidoro a la enfermería monástica, „Asclepio. Revista de la Historia de le Medicina y de la Ciencia" 72/1 (2020) s. 6.

131 Por. Isidorus Hispalensis, Regula 22.

132 Por. Isidorus Hispalensis, Regula 1.

133 Por. Isidorus Hispalensis, Regula 22.

134 Por. Isidorus Hispalensis, Regula 21.

135 Por. Isidorus Hispalensis, Regula 9.

136 Por. Isidorus Hispalensis, Sententiae II 42, 14. Zwraca na to uwagę: B. Uchoa Borgongino, A conduta dos monges enfermos na ,Regula Isidori” (615-619), w: Anais do XXVI Simpósio Nacional de História, red. M. de Moraes Ferreira, São Paulo 2011, s. 5-6.

137 Por. Isidorus Hispalensis, Regula 17; 3.

138 Por. Isidorus Hispalensis, Regula 19.

139 Por. Isidorus Hispalensis, Regula 20.

140 Por. Augustinus, Regula ad servos Dei 5. 
snych przyjemności, wygodnictwo ${ }^{141}$. Podkreśla więc, że powinni uważać zdrowych i pracujących współbraci za lepszych od siebie. Przestrzega, że choroba nie daje przywileju posiadania prywatnych rzeczy. Akcentuje, że chorzy mogą korzystać z dodatkowych kąpieli oraz prawa do przebywania na osobności wyłącznie ze względów zdrowotnych, nie zaś dla zaspokojenia zachcianek ${ }^{142}$. O niebezpieczeństwie, na które narażają się oddalający od wspólnoty niewyrobieni mnisi, Sewilczyk pisze również w rozprawie O obowiazkach kościelnych (De ecclesiasticis officiis) ${ }^{143}$. Zauważa, że zrzucając jarzmo pokory i posłuszeństwa, przenoszą się oni do osobnych cel, gdzie utwierdzają się w przekonaniu o własnej doskonałości, podczas gdy ukryte w duszach wady uśmiercają ich niczym śmiercionośna trucizna (loetale et intestinum virus), która przenika głęboko we wnętrzności i wywołuje nieuleczalną chorobę (insanabilem morbum) ${ }^{144}$.

\section{Choroba ciala, niemoc ducha}

Jak widzimy, Sewilczyk odwołuje się do doświadczenia choroby również wówczas, gdy pisze o rzeczywistości duchowej, analiza wypowiedzi zaś, w których zestawia niemoce ciała i ducha, pozwala lepiej zrozumieć, jak tę rzeczywistość postrzegał. Patrząc na pojawiających się na kartach Ewangelii niemych (muti), widzi tych, którzy nie wyznają wiary w Chrystusa ${ }^{145}$. Głusi (sordi) uosabiają jego zdaniem tych, którzy nie dają posłuchu przykazaniom, chromi (claudi) ${ }^{146}$ symbolizują tych, którzy lekceważą wypełnianie zbawiennych przykazań ${ }^{147}$, a dotknięci ślepotą (caeci)

141 Pisze o tym: J.R. Zaragoza Rubira, Enfermedad del alma y medicina del alma en la obra de San Isidoro, „Asclepio” 18-19 (1966-1967) s. 579-589. Niestety nie miałam możliwości zapoznania się z ta pracą.

142 Por. Isidorus Hispalensis, Regula 22.

143 Por. Ledzińska, Gramatyka, s. 59-61.

144 Por. Isidorus Hispalensis, De ecclesiasticis officiis II 15, 5-6.

145 Por. Isidorus Hispalensis, Allegoriae quaedam Sacrae Scripturae 144. O wizualnym wymiarze alegorycznego odczytywania Pisma pisze: K. Bardski, Słowo oczyma Gołębicy. Metodologia symboliczno- alegorycznej interpretacji Biblii oraz jej teologiczne i duszpasterskie zastosowanie, Warszawa 2007, w: http://pracownicy.uksw.edu. pl/KrzysztofBardski/publikacje/slowo-oczyma-golebicy-2/slowo-oczyma-golebicy/ (dostęp: 2.02.2021). O Izydorowym traktacie Pewne alegorie Pisma świętego pisze: Ledzińska, Gramatyka, s. 71-72.

146 Por. Isidorus Hispalensis, Allegoriae 146.

147 Por. Isidorus Hispalensis, Allegoriae 147. 
- tych, którzy nie rozumieją tego, w co wierzą ${ }^{148}$, lub jak poganie w ogóle nie otrzymali od Boga światła wiary ${ }^{149}$. Człowiek z wyschniętą kończyną (manum habens aridam) jest niczym dusza pozbawiona uczynków miłosierdzia. Uzdrawiający Chrystus nakazuje mu wyciągnąć rękę, to jest nieustannie wspierać jałmużną ubogich ${ }^{150}$. Na uwagę zasługuje zdradzająca znajomość pism poprzedników ${ }^{151}$, ale poza wszelką wątpliwością dowodząca pisarskiej samodzielności Izydora wizja paraliżu jako stanu duszy obezwładnionej przez występki (,,anima est vitiis dissoluta in corpore suo"), a przez to uzależnionej od ciała niczym przykuty do łoża paralityk (,paralyticus, iacens in lectulo"). Po odpuszczeniu grzechów powstaje ona i dźwiga ciało ku zbawieniu (,,per peccatorum remissionem sanata [...] resurgit et lectum carnis, in quo debilis ante iacebat, ad domum virtutum reportat") ${ }^{152}$.

Interesujące jest Izydorowe spojrzenie na grzech. Cielesne żądze w jego ujęciu palą niczym ogień i zatapiają jak wzbierająca woda. Porównuje je bowiem zarówno z gorączką trawiącą teściową Piotra (,febriens [...] aestu carnalium desiderium [...] accensam") ${ }^{153}$, jak też za Ambrożym z puchliną wodną, która ,polega na [nagromadzeniu] pod skórą płynu, z towarzyszącym temu bolesnym wzdęciem i cuchnącym oddechem"154: „Hydropicus demonstrat eos quos fluxus carnalium voluptatum exube-

148 Por. Isidorus Hispalensis, Allegoriae 145. Zob. Augustinus, Quaestionum Evangelicorum libri II I 19.

149 Por. Isidorus Hispalensis, Allegoriae 225. Zob. Ambrosius, Expositio Evangelii secundum Lucam VIII 80; Gregorius Magnus, Moralia in Iob XXVII 44, 72, 4-5.

150 Por. Isidorus Hispalensis, Allegoriae 163. Zob. Mt 12,10-13; Augustinus, Quaestionum II 7; Arnobius Iunior, Annotationes ad quaedam Evangeliorum loca II (Ex Matthaeo) 16.

151 Por. Augustinus, Quaestionum II 4.

152 Por. Isidorus Hispalensis, Allegoriae 159. Zob. Mt 9,1-7.

153 Por. Isidorus Hispalensis, Allegoriae 155. Zob. Mt 8,14-15. J.C. Martín-Iglesias (Las fuentes de las „, Allegoriae quaedam Sanctae Scripturae” (CPL 1190) de Isidoro de Sevilla, „Euphrosyne” 46 (2018) s. 163) słusznie zauważa podobieństwo zachodzące między tym passusem Alegorii a Objaśnieniami do Ewangelii według Mateusza autorstwa Chromacjusza. Zaznaczmy jednak, że biskup Akwilei porównuje gorączkę do ciężkich występków (por. Tractatus in Matthaeum 40, 2, 19-21: gravibus delictis), tak więc interesujące nas porównanie pochodzi od Izydora.

${ }^{154}$ Isidorus Hispalensis, Etymologiae IV 7, 23.Współczesna medycyna traktuje puchlinę wodną nie jako samodzielną jednostkę chorobową, lecz jako symptomy towarzyszące m.in. gruźliczemu zapaleniu otrzewnej, niewydolności serca, marskości wątroby (znaczne wysięki w jamach opłucnowych, jamie brzusznej). Por. Grmek, Historia, s. 64-65. 
rans aggravat" 155 - ,[...] hydropicus, in quo fluxus carnis exuberans animae gravabat officia, spiritus extinguebat ardorem" 156 .

Grzech szpeci: Sewilczyk konfrontuje go z trądem (,leprosus [...] delicti contagio maculosum") ${ }^{157}$, który powoduje powstanie na skórze ciemnych, czerwonych i białych plam, a następnie przebarwia powierzchnię całego ciała ${ }^{158}$. Grzech wywołuje ból, rozkład, fetor. Grzesznik jest niczym żebrak pokryty wrzodami (,ulcerosus”) ${ }^{159}$, gnijącymi i cuchnącymi (,ulcus putredo ipsa [...] quod olet") ${ }^{160}$. Grzech pierworodny to ciemności, w które pogrążyła się ludzkość przypominająca Sewilczykowi ślepego od urodzenia człowieka ${ }^{161}$.

\section{Przyczyny chorób}

W Sentencjach, jednym z najważniejszych i najbardziej popularnych swoich dzieł o treści dogmatycznej i dydaktyczno-moralnej ${ }^{162}$, Izydor wyraża przekonanie, że choroby dotykają ludzi z powodu grzechu (ex peccato), kuszenia (ex temptatione) oraz nieumiarkowanych pragnień (ex intemperantiae passione). Stwierdza, że medycyna może zaradzić jedynie w przypadku tych ostatnich. Nie oznacza to jednak, że Sewilczyk nawołuje do poddania się tym pierwszym. Przecież ludziom, których Bóg nawiedza, by uratować przed śmiercią wieczną, dotykając chorobami z powodu ich grzechów, przychodzi z pomocą łaskawość Jego miłosierdzia (pietas divinae misericordiae). Choroba ciała może bowiem być zbawienna (salubris infirmitas), gdy dotykając ludzi nader krzepkich i zdrowych (valentiores [...] et sani), cieszących się ,zgubnym dobrym samopoczuciem” (perniciosa sanitas), prowadzi do „usunięcia z oczu łusek niewiary" (squamae infidelitatis [...] mutatae) i ,zerwania więzów zatwardziałości serca" (resoluta [...] duritia mentis), czyli do nawrócenia

155 Isidorus Hispalensis, Allegoriae 215.

156 Ambrosius, Expositio VII 195.

157 Por. Isidorus Hispalensis, Allegoriae 150.

158 Por. Isidorus Hispalensis, Etymologiae IV 8, 11.

159 Por. Isidorus Hispalensis, Allegoriae 219.

160 Por. Isidorus Hispalensis, Etymologiae IV 8, 19.

161 Por. Isidorus Hispalensis, Allegoriae 240. Zob. J 9; Arnobius Iunior, Annotationes I (Ex Joanne) 3.

162 Por. Ledzińska, Gramatyka, s. 72-74; T. Krynicka, Wprowadzenie, w: Izydor z Sewilli, Sentencje, tł. T. Krynicka, Kraków 2012, s. 5-30. 
i zerwania ze sprowadzającą zgubę chorobą duszy - grzechem (,languor animae, id est peccatorum infirmitas, perniciosa") ${ }^{163}$. W Synonimach (Synonyma), piśmie znajdującym się na pograniczu literatury ascetycznej i gramatyki, poświęconym dramatowi ludzkich zmagań z losem ${ }^{164}$, Człowiek uświadamiający sobie, że przyczyną wszystkich doznawanych przezeń nieszczęść jest jego grzeszność, opisuje ją, posługując się leksyką medyczną, tj. właśnie jako stan chorobowy: „Ta dolegliwość (languor) jest wynikiem [twojej] własnej winy, ta choroba (aegritudo) jest wynikiem twojej własnej niegodziwości"165.

Doświadczenie grzechu jako obiektywnego zdarzenia biologicznego, wskutek którego powstają trwałe, groźne dla organizmu uszkodzenia, jeszcze wyraźniej dochodzi do głosu w zamykającej monolog Człowieka modlitwie. Szuka on ratunku u Pana, widząc w Nim w pierwszej kolejności właśnie lekarza:

Niech przed niemocą stworzenia (infirmae conditioni) stanie otworem droga ku ocaleniu. Nie są przed Tobą zakryte moje rany (vulnera), [jawna jest] przed Tobą moja choroba (aegritudo), Ty widzisz, jak bardzo jestem zraniony (saucius) i osłabiony (languidus). Daj mi lek (medicinam), który mnie uzdrowi, zastosuj lekarstwo (medellam), które mnie uleczy, odnów to, co przeżarły ułomności (infectum vitiis), napraw to, co uszkodziły grzechy (corruptum peccatis $)^{166}$.

Chrystus istotnie działa jak lekarz, kompetentny i całkowicie oddany pacjentom. Izydor pisze:

przyszedł, otworzył ranę (vulnus), siebie samego do niej przyłożył (composuit semetipsum) i ze swojej śmierci przygotował dla nas odpowiedni lek („de sua morte nobis medicinam aptavit”), aby nie być jedynie tym, który pokazuje ranę (ostensor vulneris), lecz także tym, który ją uzdrawia $(\text { sanator })^{167}$.

163 Isidorus Hispalensis, Sententiae III 3.

164 Por. A. Ledzińska, Gramatyka, s. 61-63; T. Krynicka, Wprowadzenie, w: Izydor z Sewilli, Synonimy, tł. T. Krynicka, Kraków 2017, s. 7-21.

165 Isidorus Hispalensis, Synonyma I 40.

166 Isidorus Hispalensis, Synonyma I 72.

167 Isidorus Hispalensis, Sententiae I 14, 8. 


\section{Chrześcijanin wobec choroby}

Za czasów swego ziemskiego życia Syn Boży przywracał wzrok i słuch, uzdrawiał chromych i niemych, oczyszczał trędowatych, aby ujrzeli Boga, usłyszeli i przyjęli z wiarą Jego słowo, podążyli ku Niemu, wyznając Go, oraz doznali uleczenia ran grzechu ${ }^{168}$. Jednak Izydor przestrzega czytelnika przed szukaniem cudownych uzdrowień: cudów potrzebowali poganie i niewierzący, poganina apostoł Paweł uzdrowił, lecz swemu uczniowi podał lek. Epoka znaków i nadprzyrodzonych mocy minęła, przyszły czasy składania świadectwa zacnego postępowania oraz wytrwałości w dobrym ${ }^{169}$, gdy największym, nowym cudem stało się piękno Kościoła ${ }^{170}$. Niemoc jest wpisana w nasz ziemski los. Przychodząc na świat, jesteśmy mali i bezbronni, nie potrafimy mówić ${ }^{171}$, nie rozumiemy, co czynimy ${ }^{172}$, najlepsze lata spędzamy utrudzeni ${ }^{173}$. Wreszcie nadchodzą, pozbawiając nas sił, znienawidzona, odbierająca rozum starość oraz śmiercionośne choroby ${ }^{174}$, a za nimi okrutne umieranie ${ }^{175}$. Człowiek powinien zaakceptować swoją kondycję, mając świadomość, że oferowane mu przez medyków środki lecznicze, z których ma prawo, a nawet obowiązek korzystać, nie zmienią jej definitywnie, toteż pozostaje mu cierpliwie znoszenie doczesnych udręk oraz dążenie do zawierającego pełnię życia vita vitalis - życia wiecznego ${ }^{176}$.

\section{Choroba w życiu Izydora}

Choroba naznaczyła również życie biskupa Sewilli: w listach do Brauliona prosi o modlitwę, gdy nękają go niemoce ciała i niepokój świadomego własnych przewin ducha ${ }^{177}$. Przekazuje do wykończenia ręko-

168 Por. Isidorus Hispalensis, De fide catholica contra Iudeos I 16, 2-3. Por. Ledzińska, Gramatyka, s. 77.

169 Por. Isidorus Hispalensis, Sententiae I 24.

170 Według pięknego ujęcia omawiającego analizowany passus Sentencji: P. Caziera, Isidore de Séville et la naissance de l'Espagne catholique, Paris 1994, s. 129-132.

171 Por. Isidorus Hispalensis, Etymologiae XI 11, 9.

172 Por. Isidorus Hispalensis, Etymologiae XI 11, 27.

173 Por. Isidorus Hispalensis, Etymologiae XI 11, 16.

174 Por. Isidorus Hispalensis, Etymologiae XI 11, 30; IV 5, 2.

175 Por. Isidorus Hispalensis, Etymologiae XI 11, 31.

176 Por. Isidorus Hispalensis, Sententiae III 61, 5.

177 Por. Isidorus Hispalensis, Epistulae 1, 11-12. 
pis swej encyklopedii, której ostateczną redakcję uniemożliwiła mu wyczerpująca dolegliwośćc ${ }^{178}$. Schorowany, w obliczu śmierci z poruszającą szczerością wyraża pragnienie ujrzenia przyjaciela po raz ostatni oraz prosi, by modlił się, aby Bóg pozwolił mu cieszyć się wieczną szczęśliwością ${ }^{179}$. Sewilski diakon Redemptus, który był świadkiem ostatnich miesięcy życia Sewilczyka i sporządził relację o nich ${ }^{180}$, opowiedział, że przeczuwał on własną śmierć nie dzięki widzeniom, znakom, objawieniom, w opisy których obfituje piśmiennictwo hagiograficzne ${ }^{181}$, lecz obserwując postęp swej choroby oraz towarzyszące mu osłabienie ciała (,fatigatum corpus aegritudine assidua subtiliter animae natura pervideret”). Czując, że ziemskie dni dobiegają końca, jeszcze hojniej rozdawał jałmużnę, gdy zaś jego stan gwałtownie pogorszył się (,post haec vulnere percussus est”), nasiliła gorączka (,febris in corpore convalesceret”), a żołądek odmówił przyjmowania pokarmów („cibum reiceret debilitatus stomacus") ${ }^{182}$, kazał zanieść się do bazyliki świętego Wincentego, gdzie wyznał swe grzechy, przyjął Komunię, pożegnał się z powierzonym mu ludem i udał się do celi, aby tam oczekiwać na spotkanie z Panem ${ }^{183}$. Zauważmy, że ostatnie chwile Izydora są wolne od rozpaczy. Dzięki mocy otrzymanej od swego Zbawcy staje się silniejszy od wielkich klasycznych herosów: nie szuka uwolnienia od bólu ${ }^{184}$, ale prosi Boga i bliźnich o przebaczenie. Nie przywołuje lekarzy, ale Pana, który wskrzesił Łazarza $^{185}$, toteż $\mathrm{w}$ swoim miłosierdziu nie pozwoli również jemu, swe-

178 Por. Isidorus Hispalensis, Epistulae 6, 12-14.

179 Por. Isidorus Hispalensis, Epistulae 8, 2-6. O listach Izydora, zob. Ledzińska, Gramatyka, s. 99; T. Krynicka, „Dulce mihi fuit diu ad te loqui” (Braulio, ep. 5, 107): korespondencja Izydora z Sewilli i Brauliona z Saragossy, „Scripta Classica” 17 (2020) (w druku).

180 Por. M.J. Kelly, The Politics of History-Writing, w: Isidore, red. A. Fear - J. Wood, Amsterdam 2016, s. 95.

181 Zwraca na to uwagę: P. Castillo Maldonado, La muerte de Isidoro de Sevilla: apuntes de crítica histórico-hagiográfica, „Habis” 32 (2001) s. 583, 586-587.

182 Por. Redemptus Clericus Hispalensis, Obitus Beatissimi Isidori Hispalensis Episcopi 2.

183 Por. Redemptus Clericus Hispalensis, Obitus Beatissimi Isidori Hispalensis Episcopi 2-6.

184 Por. Isidorus Hispalensis, Chronica I 90: „Huius tempore Hercules quinquagesimum secundum annum agens ob morbi dolorem sese flammis iniecit”. O Kronice Izydora, por. Ledzińska, Gramatyka, s. 74.

185 Por. Redemptus Clericus Hispalensis, Obitus Beatissimi Isidori Hispalensis Episcopi Obitus 3. 
mu słudze, doświadczyć wiecznej śmierci. Nie usiłuje zwalczyć chorobę, gdyż rozumie, że otworzy mu ona drzwi tam, ,gdzie płynie rzeka, w której wodach zostanie ochrzczony świat, gdzie rośnie drzewo życia - Jezus Chrystus" $" 186$.

\section{Podsumowanie}

Izydor widzi świat w świetle Objawienia, dzięki czemu jego spojrzenie jest niezwykle szerokie. Nie przeciwstawia rzeczywistości doczesnej oraz wiecznej - w jego odczuciu przenikają się one i składają na całość Bożego dzieła. Mówiąc o chorobie, niezmiennie, niezależnie od charakteru pisma podkreśla, że jest ona czymś bezwarunkowo złym. Postrzega ją jako wynik ludzkiego grzechu wpisany w ludzką kondycję, podobnie jak inne nękające nas słabości. Bada jej fizyczne i duchowe przyczyny, doszukuje się naturalnych i nadprzyrodzonych środków zaradczych. Uważa, że mamy prawo, a nawet obowiązek zwracać się po pomoc do medyków, których dorobek zna i szanuje, lecz przy tym powinniśmy pamiętać, że zdrowie - przede wszystkim ducha, jak również ciała - może nam zapewnić wyłącznie życie w jedności z Bogiem. Za najbardziej niebezpieczną uznaje chorobę duszy, czyli grzech; spośród schorzeń cielesnych wyróżnia jako najgroźniejsze morowe powietrze. Posługuje się związanymi z chorobą wyrażeniami metaforycznymi do opisania rzeczywistości grzechu. Stosując alegoryczną metodę interpretacji Pisma, widzi w chorobach ukazanych na stronach Biblii symbole duchowego zła. Wykazując się zmysłem praktycznym, opisuje troskliwą opiekę ze strony zdrowych, która należy się chorym. Wspomina, że na leczeniu znał się apostoł Paweł; jako wielkiego lekarza ludzkości ukazuje Chrystusa. Dzięki lekturze listów Sewilczyka oraz relacji o jego śmierci skomponowanej przez diakona Redemptusa wiemy, że on sam także doświadczał chorób, a znosił je tak, jak zalecał to czynić innym, to jest wytrwale, pokornie i cierpliwie dążąc do pełni życia, dla której zostaliśmy stworzeni i zbawieni.

186 Isidorus Hispalensis, In libros Veteris ac Novi Testamenti Proemia 109. O piśmie Wstepy do ksiag Starego i Nowego Testamentu, por. Ledzińska, Gramatyka, s. 56-57. 


\title{
A Disease in Isidore of Seville's Selected Writings
}

\author{
(summary)
}

Isidore looks at the world in the light of the Revelation, so that his look becomes really broad. He does not oppose the terrestrial to the eternal: in his feeling they permeate each other and make up the entirety of God's work. Writing about the disease, he underlines that it is unconditionally evil. He studies its physical and spiritual causes and seeks both natural and supernatural remedies. He believes we may and even have to look for doctors' help, he knows and respects ancient medicine's legacy, but at the same time he considers sickness to be a result of the human sin and stresses that the true health can be achieved only by living in unity with God. In Isidore's opinion the most dangerous illness is that of the human spirit, i.e. the sin. As to the terrestrial maladies, he describes in the most profusive way the plague. He uses metaphors related to disease in order to describe the reality of sin; employing means of allegorical interpretation of the Holy Writ, he regards sickness as a symbol of spiritual evil. He emphasizes that the sick deserve to be cared for and treated with kindness; he describes nursing the sick monks. He informs that apostle Paul cured his disciple and presents Christ as a great doctor of the mankind. Isidore himself experimented diseases. He faced them accordingly to what he recommended to the others, bravely and patiently looking for the vita vitalis, for which all of us have been created and saved.

Keywords: Isidore of Seville; Etymologies; ancient and medieval medicine; monastic life; allegoric interpretation of Holy Scripture; disease; plague; sin; salvation

\section{Choroba w wybranych pismach Izydora z Sewilli}

\section{(streszczenie)}

Izydor z Sewilli pisze o chorobie w wielu utworach różniących się tematyką i charakterem. Postrzega ją jako bezwarunkowe zło. Bada jej fizyczne i duchowe przyczyny, doszukuje się naturalnych i nadprzyrodzonych środków zaradczych. Uważa, że mamy prawo, a nawet obowiązek zwracać się po pomoc do medyków, których dorobek zna i szanuje, lecz przy tym powinniśmy pamiętać, że zdrowie - przede wszystkim ducha, jak również ciała - może nam zapewnić wyłącznie życie w jedności z Bogiem. Za najbardziej niebezpieczną chorobę uznaje niemoc duszy, czyli grzech. Spośród schorzeń cielesnych wyróżnia jako najgroźniejsze morowe powietrze. Posługuje się związanymi z chorobą wyrażeniami metaforycznymi do opisania rzeczywistości grzechu. Stosując alegoryczną metodę interpretacji Pisma, widzi w chorobach ukazanych na stronach Biblii symbole duchowego zła. Podkreśla, że chorym należy się troskliwa, pełna czułości opieka ze strony zdrowych. Dzięki lekturze listów Sewilczyka oraz relacji o jego śmierci wiemy, że on sam także doświadczał chorób, a znosił je tak, jak zalecał to czynić innym, to jest wytrwale, pokornie i cierpliwie dążąc do pełni życia, dla której zostaliśmy stworzeni i zbawieni.

Słowa kluczowe: Izydor z Sewilli; Etymologie; starożytna i średniowieczna medycyna; monastycyzm; alegoryczna interpretacja Pisma Świętego; choroba; pomór; grzech; zbawienie 


\section{Bibliografia}

\section{Źródła}

Ambrosius, Expositio Evangelii secundum Lucam, PL 15, 1527-1850.

Arnobius Iunior, Annotationes ad quaedam Evangeliorum loca, PL 53, 569-580.

Augustinus, De Genesi ad litteram, PL 34, 245-486.

Augustinus, Quaestionum Evangelicorum libri II, PL 35, 1321-1364.

Augustinus, Regula ad servos Dei, PL 32, 1377-1384.

Cassiodorus, Institutiones, red. R.A.B. Mynors, Oxford 1937.

Cornelius Celsus, De medicina, t. 1-3, red. W.G. Spencer, London - Cambridge 1960-1961.

Chromatius Aquiliensis, Tractatus in Matthaeum, red. J. Étaix - J. Lemarié, CCL 9a, Turnhout 1974.

Galenus, De methodo medendi, t. 10, red. C.G. Kühn, Lipsiae 1825.

Gregorius Magnus, Moralia in Iob, red. M. Adriaen, CCL 143-143b, Turnhout 1979-1985.

Isidorus Hispalensis, Allegoriae quaedam Sacrae Scripturae, PL 83, 97-130.

Isidorus Hispalensis, Chronica, red. J.C. Martín, CCL 112, Turnhout 2003.

Isidorus Hispalensis, De ecclesiasticis officiis, ed. C.M. Lawson, CCL 113, Turnhout 1989.

Isidorus Hispalensis, De fide catholica ex Veteri et Novo Testamento contra Iudeos, PL 83, 449-538.

Isidorus Hispalensis, De ortu et obitu Patrum. Vida y muerte de los santos, ed. J. Chaparro Gómez, Collection Auteurs Latins du Moyen Âge, Paris 1985.

Isidorus Hispalensis, De rerum natura, w: Isidorus Hispalensis, Traité de la Nature, ed. J. Fontaine, Bordeaux 1960.

Isidorus Hispalensis, Differentiae (Diferencias) Libro I, ed. C. Codoñer, Collection Auteurs Latins du Moyen Âge, Paris 1992.

Isidorus Hispalensis, Differentiarum Liber II, ed. M.A. Andrés Sanz, CCL 111a, Turnhout 2006.

Isidorus Hispalensis, Epistulae, w: Epistolario de San Braulio, ed. L. Riesco Terrero, Sevilla 1975, s. 62-76.

Isidorus Hispalensis, Etymologiae, w: Isidorus Hispalensis, Étymologies. Livre I: La grammaire, ed. O. Spevak, Collection Auteurs Latins du Moyen Âge, Paris 2020; Étymologies. Livre XVII: De l'agriculture, ed. J. André, Collection Auteurs Latins du Moyen Âge, Paris 1981; Etimologías. Liber IV. De medicina, t. 1-2, ed. J. Oroz Reta - M.-A. Marcos Casquero, Madrid 1982; Etimologías. Libro VI. De las Sagradas Escrituras, ed. J. Chaparro Gómez, Collection Auteurs Latins du Moyen Âge, Paris 2012; Etimologie. Libro XI. De homine et portentis, ed. F. Gasti, Collection Auteurs Latins du Moyen Âge, Paris 2010.

Isidorus Hispalensis, Historia de regibus Gothorum, Wandalorum et Sueborum, PL 83, 1057-1082.

Isidorus Hispalensis, In Libros Veteris ac Novi Testamenti Proemia, PL 83, 155-180. 
Isidorus Hispalensis, Regula, red. J. Campos Ruiz - I. Roca Melia, Madrid 1971.

Isidorus Hispalensis, Sententiae, ed. P. Cazier, CCL 111, Turnhout 1998.

Isidorus Hispalensis, Synonyma, ed. J. Elfassi, CCL 111b, Turnhout 2009.

Isidorus Hispalensis, Versus, red. J.C. Sánchez Martín, CCL 113a, Turnhout 2000.

Marcellus, De medicamentis liber, red. G. Helmreich, Lipsiae 1889.

Plinius, Historia naturalis, w: Plinius, Natural History, ed. H. Rackham - W.H.S. Jones, London - Cambridge 1963.

Publius Vergilius Maro, Aeneis, w: Publius Vergilius Maro, Aeneis (Énéide), t. 1-2, ed. H. Goelzer, Paris 1970-1974.

Redemptus Clericus Hispalensis, Obitus Beatissimi Isidori Hispalensis Episcopi, w: Scripta de vita Isidori Hispalensis Episcopi, ed. J.C. Martín-Iglesias, CCL 113b, Turnhout 2006, s. 379-388.

Scribonius Largus, Compositiones, red. S. Sconocchia, Lipsiae 1983.

Terentius, Commedie, ed. O. Bianco, Torino 1993.

\section{Opracowania}

Albrecht M. von, A History of Roman Literature from Livius Andronicus to Boethius, t. 1-2, Leiden 1997.

Bardski K., Słowo oczyma Gołęicy. Metodologia symboliczno-alegorycznej interpretacji Biblii oraz jej teologiczne i duszpasterskie zastosowanie, Warszawa 2007.

Beagon M., Variations on a Theme. Isidore and Pliny on Human and Human-Instigated Anomaly, w: Isidore of Seville and His Reception in the Early Middle Ages. Transmitting and Transforming Knowledge, red. A. Fear - J. Wood, Amsterdam 2016, s. 57-74.

Bednarczyk A., Medycyna i filozofia w starożytności, Warszawa 1999.

Castillo Maldonado P., La muerte de Isidoro de Sevilla: apuntes de crítica histórico-hagiográfica, „Habis” 32 (2001) s. 577-596.

Cazier P., Isidore de Séville et la naissance de l'Espagne catholique, Paris 1994.

Clarke M.L., Higher Education in the Ancient World, London 1971.

Collins R., Visigothic Spain 409-711, Oxford 2004.

Cytowska M. - Szelest H., Literatura rzymska. Okres cesarstwa, Warszawa 1992.

Díaz P.C., Teoría y práctica de la medicina visigoda. Del enciclopedismo de Isidoro a la enfermería monástica, „Asclepio” 72/1 (2020) s. 1-16.

Díaz y Díaz M.C., Introducción general a San Isidoro de Sevilla, w: San Isidoro de Sevilla, Etimologías. Edición bilingüe, texto latino, versión española y notas, t. 1-2, ed. J. Oroz Reta - M.-A. Marcos Casquero, Biblioteca de Autores Cristianos 433434, Madrid 1982, s. 1-257.

Díaz y Díaz M.C., Introducción, w: M.C. Díaz y Díaz, Los capítulos sobre los metales de las „Etimologías” de Isidoro de Sevilla, León 1970, s. 11-34.

Elfassi J., Isidore of Seville and the „Etymologies”, w: A Companion to Isidore of Seville, red. A. Fear - J. Wood, Leiden 2020, s. 245-278. 
Ferraces Rodríguez A., Aspectos léxicos del libro IV de las „Etimologías” en manuscritos médicos altomedievales, w: Isidorus medicus. Isidoro de Sevilla y los textos de medicina, red. A. Ferraces Rodríguez, A Coruña 2005, s. 97-127.

Ferraces Rodríguez A., Isidoro de Sevilla y los textos de medicina, w: Isidorus medicus. Isidoro de Sevilla y los textos de medicina, red. A. Ferraces Rodríguez, A Coruña 2005, s. 11-38.

Ferraces Rodríguez A., La transmisión del „De materia médica” en latín: de Dioscórides a Isidoro de Sevilla y algunos tratados de botánica, Santiago de Compostela 1996.

Fontaine J., Isidore de Séville et la culture classique dans l'Espagne wisigothique, t. 1-3, Paris 1959-1983.

Fontaine J., Isidore de Séville. Genèse et originalité de la culture hispanique au temps de Wisigoths, Turnhout 2001.

Fontaine J., Problèmes de méthode dans l'étude des sources isidoriennes, w: Isidoriana, red. M.C. Díaz y Díaz, León 1961, s. 115-131.

García García I. - Ramos Cobos M. - Gozalbes Cravioto E., Enfermedad y Cuidados en la Obra de Isidoro de Sevilla, „Index de Enfermería” 14/51 (2005) s. 70-73.

Ghellinck J. de, Patristique et Moyen Âge. Études d'histoire littéraire et doctrinale, t. 1-2, Bruxelles 1961.

Gliński Z. - Grzegorczyk K., Dżuma nadal jedna z najniebezpieczniejszych chorób, „Życie Weterynaryjne” 94/1 (2019) s. 18-24.

González T., La Iglesia desde la conversión de Recaredo hasta la invasión árabe, w: Historia de la Iglesia en España, t. 1, red. R. García Villoslada, Madrid 1979, s. 401-748.

Grmek M., Historia chorób u zarania cywilizacji zachodniej, tł. A.B. Matusiak, Warszawa 2002.

Gourevitch D., Les maladies sous le regard du compilateur: métaphores végétales et animales, w: Isidorus medicus. Isidoro de Sevilla y los textos de medicina, red. A. Ferraces Rodríguez, A Coruña 2005, s. 176-195.

Houston G.W., Inside Roman Libraries. Books Collections and Their Management in Antiquity, North Carolina 2014.

Kelly M.J., The Politics of History-Writing, w: Isidore of Seville and His Reception in the Early Middle Ages. Transmitting and Transforming Knowledge, red. A. Fear J. Wood, Amsterdam 2016, s. 93-110.

Kirk G.S. - Raven G.E. - Schofield M., Filozofia przedsokratejska, tł. J. Lang, Poznań 2009.

Klibansky R. - Panofsky E. - Saxl F., Saturn and Melancholy. Studies in the History of Natural Philosophy, Religion and Art, Nendeln 1979.

Korus K., Nauka i studia nad filozofia, w: Literatura Grecji starożytnej, t. 2, red. H. Podbielski, Lublin 2005, s. 897-918.

Kowalski M., Biskup krakowski Marcin Szyszkowski a konsekwencje zarazy lat dwudziestych XVII stulecia, w: Człowiek i przyroda w średniowieczu $i$ we wczesnym okresie nowożytnym, red. W. Iwańczak - K. Bracha, Warszawa 2000, s. 227-244. 
Krynicka T., „Dulce mihi fuit diu ad te loqui” (Braulio, ep. 5, 107): korespondencja Izydora z Sewilli i Brauliona z Saragossy, „Scripta Classica” 17 (2020) (w druku). Krynicka T., Izydor z Sewilli, Kraków 2007.

Krynicka T., Izydora z Sewilli „, O narodzinach i śmierci” świętych ojców: kompozycja traktatu, „Vox Patrum” 73 (2020) s. 95-121.

Krynicka T., Kwintus Gargiliusz Marcjalis - żotnierz, pisarz i ogrodnik, w: Gargiliusz, Lekarstwa z warzyw i owoców, tł. T. Krynicka, Wrocław 2016, s. 11-27.

Krynicka T., Literacki charakter botanicznej wiedzy Izydora z Sewilli (,Etymologie”, Ksiega XVII), „Studia Classica et Neolatina” 9 (2010) s. 23-36.

Krynicka T., Świat roślin w XVII księdze „Etymologii” Izydora z Sewilli, Lublin 2007.

Krynicka T., Wprowadzenie, w: Izydor z Sewilli, Sentencje, tł. T. Krynicka, Kraków 2012, s. 5-30.

Krynicka T., Wprowadzenie, w: Izydor z Sewilli, Synonimy, tł. T. Krynicka, Kraków 2017, s. 7-21.

Krynicka T., Wstęp, w: Izydor z Sewilli, Wiersze, tł. T. Krynicka, „Vox Patrum” 50-51 (2007) s. 565-580.

Kuźmiak K., Kosma i Damian, EK IX 928.

Langslow D.R., Medical Latin in the Roman Empire, Oxford 2000.

Le Goff J., Kultura średniowiecznej Europy, tł. H Szymańska-Grossowa, Warszawa 1970. Ledzińska A., Gramatyka wobec sztuk wyzwolonych w pismach Izydora z Sewilli. „,Origo et fundamentum liberalium litterarum”, Kraków 2014.

Maire B., Isidore de Séville, lecteur de Gargilius Martialis, w: Isidorus medicus. Isidoro de Sevilla y los textos de medicina, red. A. Ferraces Rodríguez, A Coruña 2005, s. 198-213.

Marrou H.-I., Historia wychowania w starożytności, tł. S. Łoś, Warszawa 1969.

Martín-Iglesias J.C., Las fuentes de las „, Allegoriae quaedam Sanctae Scripturae” (CPL 1190) de Isidoro de Sevilla, „Euphrosyne” 46 (2018) s. 143-179.

Nutton V., Ancient Medicine, London 2013.

O'Loughlin T., Isidore of Seville as a Theologian, w: A Companion to Isidore of Seville, red. A. Fear - J. Wood, Leiden 2020, s. 135-152.

Osbaldestone T.A., Introduction, w: Dioscorides, De materia medica. Being an herbal with many others medicinal materials, t1. T.A. Osbaldestone, Johannesburg 2010, s. XX-XXXVIII.

Pigeaud J., De la mélancolie et de quelques autres maladies dans les Étymologies d'Isidore de Séville, w: Textes médicaux latins antiques, red. G. Sabbah, Saint-Étienne 1984, s. 87-109.

Ribémont B., Les origines des encyclopédies médiévales. D'Isidore de Séville aux Carolingiens, Paris 2001.

Scarborough J., Medical Terminologies: Classical Origins, Oklahoma 1992.

Sotomayor y Muro M., La Iglesia en la España Romana, w: Historia de la Iglesia en España, t. 1, red. R. García Villoslada, Madrid 1979, s. 7-400. 
Strzelczyk J., Goci-rzeczywistość i legenda, Warszawa 1984.

Turasiewicz R., Pisma medyczne. Corpus Hippocraticum, w: Literatura Grecji starożyt$n e j$, t. 2, red. H. Podbielski, Lublin 2005, s. 491-504.

Uchoa Borgongino B., A conduta dos monges enfermos na „, Regula Isidori” (615-619), w: Anais do XXVI Simpósio Nacional de História, red. M. de Moraes Ferreira, São Paulo 2011, s. 1-10.

Vásquez Buján M.E., Isidoro de Sevilla y los libros de medicina, A propósito del antiguo comentario latino a los „Aforismos” hipocráticos, w: Isidorus medicus. Isidoro de Sevilla y los textos de medicina, red. A. Ferraces Rodríguez, A Coruña 2005, s. 131-174.

Wallis F., Isidore of Seville and Science, w: A Companion to Isidore of Seville, red. A. Fear - J. Wood, Leiden 2020, s. 182-222.

Winniczuk L., Ludzie, zwyczaje i obyczaje starożytnej Grecji i Rzymu, Warszawa 2006. Zaragoza Rubira J.R., Enfermedad del alma y medicina del alma en la obra de San Isidoro, „Asclepio” 18-19 (1966-1967) s. 579-589. 